\title{
Stability, resilience and sustainability: a tribute to Ramon Margalef, 10 years after his death
}

\author{
Narcís Prat*
}

Grup de Recerca F.E.M. (Freshwater Ecology and Management). Departament d'Ecologia. Universitat de Barcelona, Diagonal, 643. 08028 Barcelona. Spain.

* Corresponding author: nprat@ub.edu

Received: 01/12/2014

Accepted: 11/06/2015

\begin{abstract}
Stability, resilience and sustainability: a tribute to Ramon Margalef, 10 years after his death

The plenary session of the XVI Asociación Ibérica de Limnología (AIL) congress was devoted to remembering Professor Margalef on the occasion of the $10^{\text {th }}$ anniversary of his death. Based on the main theme of the congress, i.e., "Understanding the resilience of aquatic ecosystems, basis for a sustainable future", I take the occasion to review the main ideas about ecology according to Margalef using as key words the concepts of stability, resilience and sustainability. I analyse the use of those terms by Margalef in his writings and especially in the six major books he published during his life. I also examine how those terms have been used since 1997 (the date of his latest book) in the journals Ecology and Frontiers in Ecology and Evolution. In the 1970s, Margalef published several papers discussing the term stability in ecology; however, towards the end of his life, he completely abandoned its use. Neither resilience nor sustainability played important roles in his writings. None of these three words relate to his ideas of ecology, despite the fact that they are currently used in ecology and environmental sciences. I conclude that today, much of Margalef's work is ignored by ecologists, and this omission is partly due to their personal views of what ecology should be.
\end{abstract}

Key words: Stability, resilience, sustainability, Margalef.

\section{RESUMEN}

Estabilidad, resiliència y sostenibilidad: Homenaje a Ramon Margalef a los 10 años de su muerte

El XVI congreso de la AIL ha querido dedicar la ponencia central del congreso a recordar la figura del Profesor Margalef en ocasión del 10 aniversario de su muerte. En este trabajo y usando el tema principal del congreso "Entendiendo la resiliencia de los ecosistemas acuáticos, la base para un futuro sostenible" aprovechamos para recordar cuales eran las ideas centrales de la ecología según Margalef, usando como palabras clave estabilidad, resiliencia y sostenibilidad. Analizamos el uso de estos términos en las obras de Margalef y especialmente en sus 6 libros principales. También examinamos como estos tres términos se han venido usando en dos de las principales revistas de ecología "Ecology" y "Frontiers in Ecology and Environment" desde 1997, fecha del último libro de Margalef. Aunque Margalef usó extensivamente el concepto de estabilidad en los años setenta, abandonó por completo su uso en las etapas finales de su vida. Ni resiliencia ni sostenibilidad forman parte de forma habitual de sus trabajos. Ninguno de estos tres conceptos forma parte de lo que el concibe que debe ser la ecología moderna en su libro de 1997 a pesar que los tres están muy presentes en los libros y trabajos actuales de ecología y ciencias ambientales. Concluimos que hoy en día gran parte del trabajo de Margalef es ignorado y ello se debe en gran parte a su particular idea de lo que debería ser la Ecología.

Palabras clave: Estabilidad, resiliencia, sostenibilidad, Margalef. 


\section{INTRODUCTION}

This work was conceived for the inaugural lecture of the XVI Congress of the Iberian Association of Limnology (AIL), which took place in Santander in July 2014, the year of the $10^{\text {th }}$ anniversary of the death of Professor Margalef. It was a great honour for the author to have been chosen to present this paper at the inaugural conference as a former student of Professor Margalef and chairman of the AIL (AEL at the time) during its first 12 years. The theme of the meeting was "Understanding the resilience of aquatic ecosystems, basis for a sustainable future". Within this framework, the aim of this paper was to review the ideas and opinions about the concepts used by Professor Margalef. In addition, I explain who Margalef was, the essential characteristics of his work, and the pivotal role he played in the development of ecology and limnology in Spain and Latin America.

Throughout 2014, various events commemorating the $10^{\text {th }}$ anniversary of Professor Margalef's death were organized under the banner "Remembering the master, Ramón Margalef (1919-2004)". I want to emphasize the role of Ramón Margalef during his years as Professor of the University of Barcelona, teacher of teachers and master of a generation of biologists, researchers and professionals. The commemorative events (lectures, exhibitions, among others) showed that Margalef is still vividly remembered by those who knew him; however, he is only vaguely known by younger generations. Although the main Biology building of the University of Barcelona carries his name, several students admit not knowing more than the fact that Margalef "is a man who has a commemorative plaque at the entrance of the building". This oblivion is another reason to take this $10^{\text {th }}$ anniversary to remember the importance of his work. The celebratory activities are available on the following website: http://www.ub.edu/laubdi vulga/margalef/index.html.

Six of the books published by Margalef summarized his perception of ecology. Two were university textbooks (Ecologia, 1974a and Limnologia, 1983). In the other four books, he syn- thesized the knowledge he treasured throughout his life: 1) Perspectives of Ecological Theory (Margalef, 1968); 2) La Biosfera entre la Termodinámica y el Juego (Margalef 1981); 3) Teoría de Sistemas Ecológicos (1991), and 4) Our Biosphere (1997a). Today, these works are almost completely ignored in the scientific literature. Only the first of his books has a few citations in the Web of Science (32 in total since its publication), while the other 3 have 0 citations; the same is true for the two textbooks. Margalef's ultimate objective was to establish ecology as a science with a unified body of theory comparable to several other sciences such as physics (Margalef, 1968). However, the idea of what is the ecological theory according to Margalef (1997a) does not coincide with most of the research performed at that time on this topic. Therefore, the book "Our Biosphere" is nearly unknown among ecologists.

Margalef was recognized and esteemed by most of those who knew him as a scholar and teacher, and he was well-known for his conferences and seminars that tended to be provocative and focussed on the uncertainties rather than on well-established ideas. Margalef was a prolific writer; his list of publications amounts to 563. However, his publications in SCI journals (20 journals, 34 papers) are relatively few compared to the volume of his publications because several of his texts were published in book chapters or conference proceedings (Prat, 2015). Today, Margalef's name remains absent from the most used textbooks in ecology (e.g., Townsend et al., 2008; Molles, 2013; Prat, 2015).

This paper is not a personal or scientific biography of Dr. Margalef. After his death various papers with different orientations have been published, such as those by Ros (2006), Armengol (2006), Gracia (2008) and Peters (2010). During his lifetime a relatively extensive biography by Bonnin (1994) was also published. The scientific contributions of Margalef were analysed in three monographs that appeared after his death, namely a special issue of the journal "Ecosistemas" (Zamora et al., 2005), the proceedings of a conference in his honour (Valladares et al., 2008), and a volume of the journal "Limnetica" (Armengol et al., 2006). 
This paper is based on the theme of the XVI AIL Congress (Understanding the resilience of aquatic ecosystems: basis for a sustainable future). However, neither resilience nor sustainability were important issues in Margalef's work. If I had to limit this paper to the number of times the two concepts appeared in his books or other publications, this paper would end here. Therefore, I extended the title and analysis of these terms to a concept closely related to resilience and that is sufficiently treated in the work of Dr. Margalef, i.e., stability. This concept remains a complex and controversial issue, especially when related to diversity. However, discussing in detail the stability-diversity relationship would take a considerable length of time and probably the contribution I could make to this issue would not be relevant. Other authors have discussed it rigorously enough (Flos, 2005; Estrada, 2008). My approach is historical, and I will occasionally use Margalef's own words to discuss the importance of those terms in his work.

\section{THE SCIENTIFIC LEGACY OF PROFESSOR MARGALEF}

The total number of Margalef's writings is 563, according to the two most comprehensive lists published (Ros, 2006 and Peters, 2010) and considering the documents housed at the library of the Biology department of the University of Barcelona (Margalef Fund). This list includes articles in journals, book chapters, whole books, congress proceedings, and others, such as book prefaces and abstracts. All of this material was written between 1943 and 2005, which represents an average of approximately eight documents per year in 106 different journals. Many works were published in conference proceedings (54); book chapters (141), and books (31). The journals in which more papers were published included "Investigaciones Pesqueras/Scientia Marina" (59) and "Publicaciones del Instituto de Biología Aplicada" (50). In most journals (64), he published only once; in 26 journals, between two and five times; in 10 journals, between six and 10 times; and in seven journals, more than 10
Table 1. Percentage of words that appear in the table of contents of the first book by Margalef (Perspectives in Ecological Theory, 1968), and the percentage of words counted in the text of his latest book (1997a). Only those present at a rate higher than $2.98 \%$ have been considered. Porcentaje de las palabras que salen en el índice de contenidos del primer (Margalef, 1968) y porcentaje de las palabras contadas en el texto del último libro de Margalef, (1997a). Sólo aquellas presentes en un porcentaje superior al $2.98 \%$ han sido consideradas.

\begin{tabular}{lcc}
\hline & PET & OB \\
\hline Core words & & \\
\hline Succession & 10.93 & 6.75 \\
Information & 9.60 & 5.25 \\
Ecosystems & 8.94 & 4.74 \\
Diversity & 6.29 & 4.57 \\
Energy & 6.29 & 5.85 \\
Evolution & 5.96 & 5.77 \\
Phytoplankton/plankton & 5.96 & 4.02 \\
\hline
\end{tabular}

Losers

\begin{tabular}{lll}
\hline Exploitation & 4.64 & 0.43 \\
Lakes & 3.64 & 0.64 \\
Feedback & 3.31 & 0.13 \\
Chlorophyll & 3.31 & 0.94 \\
Pigments & 2.98 & 0.38 \\
Biomass & 2.98 & 1.88 \\
Species & 2.32 & 7.01 \\
Niche & 2.31 & 0.19 \\
Ecology & 1.99 & 2.99 \\
Production & 1.66 & 3.97 \\
Stability & 1.32 & 0.17 \\
\hline Winners & & \\
\hline Life & 0.33 & 6.19 \\
Populations & 0.33 & 3.76 \\
Organization & 0.00 & 3.18 \\
Phosphorous & 0.00 & 1.74 \\
Size & 0.00 & 2.31 \\
\hline
\end{tabular}

times. Most journals in which he published are not in the first quartile of their category in the SCI system. For example, Margalef has only three papers in the journal "Limnology \& Oceanography". The journal in the Web of Science in which he published more frequently was "Hydrobiologia" (4 times). This pattern is due to several reasons; the most important reason is that Margalef never considered the "impact index" as a relevant issue. Of course, early in his career this was not generally considered as 
an important issue, at least, not in Spain, where, until the beginning of the 1990s, the SCI impact index was not used for evaluating the research production. He preferred books rather than papers in journals, which are usually limited to a few pages, because in books there is space to develop scientific arguments in more detail. Margalef also considered book chapters important, especially those in books resulting from scientific meetings or other initiatives where it was possible to discuss a topic in depth. Margalef liked scientific discussions, especially with colleagues from other disciplines.

Margalef fluently spoke several languages and could read others relatively well (including Russian). Hence, he was familiar with the global literature on ecology and limnology. In his book "Ecologia" (Margalef, 1974a), he included 2910 references, and in his book "Limnologia" (Margalef, 1983a), he included 4274. Most of his work is written in Spanish (60.4\%), but he also published in English (approximately $20 \%$ ) and in Catalan $(13 \%)$. The use of language changed over time due to historical circumstances. At first, he wrote almost exclusively in Spanish. Over time, the ratio between the three languages became more balanced, and an increasing number of manuscripts were written in Catalan. In addition, he regularly published in French, almost always as a result of invitations to give lectures or attend meetings in France. A more detailed analysis of such quantitative measures of Margalef's use of references and languages might be found in Prat (2015).

\section{ECOLOGY ACCORDING TO MARGALEF}

Did Margalef have his own definition of ecology? Has his perception evolved over time? I will try to answer these questions using a very simple approach: a comparison between the words that Margalef used the most in his first and last books (1968; 1997a). I believe that this comparison might shed light on the concepts that have always been important for Margalef, those for which he lost his interest in over time and those that appeared only later. This comparison is espe- cially significant for the words I am specifically analysing in this paper: stability, resilience and sustainability.

In the book Ecología (Margalef, 1974a), ecology is defined as "the biology of ecosystems" and, more formally, as "the study of systems to a level at which individuals or whole organisms can be considered elements of interaction among them or with a loosely organized environmental matrix". In the Preface of the 1968 book, he wrote "My only goal is to establish the context in which I think it is possible to speak of an ecological theory". However, 30 years later, in the first chapter of his book "Our Biosphere", he seemed to have lost interest in defining ecology; he stated, "I will speak of ecosystems, but I will be relatively informal about where to place the limits", and later he stated, “... What is ecology and what is not? What is theory and what is reality? Most of these might be academic questions in the sense of being irrelevant or unproductive". At the end of the introduction he warned about this issue: "In the more formal Ecology of today, one reads about 'concepts' such as niche, patchiness, the paradox of the plankton, 'top-down' or 'bottom-up' control, but one feels an utter lack of general theory that could provide a link between so many disparate subjects". It seems that Margalef recognized, in 1997, that he could not achieve his 1968 goal, i.e., to formulate an integrative ecological theory. Margalef's dissatisfaction is reflected in a phrase at the beginning of "Our Biosphere": "my only regret is that I do not feel satisfied with the way I have tried to integrate, discuss and digest the information at hand". This statement does not imply that Margalef did not try repeatedly to integrate his ecological knowledge.

The two books I compare here, written 30 years apart, are different in length (110 versus 176 pages; approximately 40000 versus 65000 words; and 4 versus 11 chapters), but most of the topics covered are the same. The permanence of Margalef's ideas is shown by comparing the most commonly used words in both books (Table 1). I find three categories of words: those that remain the core of both books (similar use and up to $4 \%$ ), the losers (nearly disappearing in the 1997 
book) and the winners (nearly absent in the 1968 book but frequent in the 1997 book).

The core words (Table 1) are succession, information, ecosystems, diversity, energy, evolution, plankton/phytoplankton, production and ecology. The winners are species, life, populations, organization, phosphorous, and size. The most relevant losers are exploitation, lakes, feedback, chlorophyll, pigments, biomass, stability and niche. Neither resilience nor sustainability appear in these books. Of course, sustainable or sustainability cannot be expected to be present in the 1968 book, but in 1997, both were well established terms in the scientific literature. Resilience was a frequent term in 1968 and in 1997, although not as popular as today. Why did Margalef not use these words frequently? Why did he abandon the use of stability while he proposed mathematical expressions to quantify it in certain books and papers (Margalef, 1981)? In the following paragraphs, I will synthesize the current use of the three terms in a relevant part of the ecological literature and explore reasons why Margalef used or not these concepts.

\section{STABILITY}

Stability is a classic term in ecology. When the book "Perspectives in Ecological Theory" (Margalef, 1968) was published, it was almost impossible to speak about ecology without mentioning stability. Ecologists were especially concerned at the time about the relationship between diversity and stability (Margalef, 1969; 1974b). However, one of the problems with the use of this term in ecology is that from the beginning, it had two contradictory meanings: $i$ ) the consistency of environmental conditions over time, and $i i)$ the ability of the system to remain reasonably equal to itself despite the occurrence of major environmental changes. According to Margalef, in the first case, the system reached a steady state under constant conditions, while the second shows a greater resistance to change. Several authors have studied the concept of stability in ecology and defined new terms (Orians, 1974). Margalef addressed the issue in different publications (Margalef, 1969, 1974b, 1975, 1977) and expressed very early on his intention to abandon this concept. "It now seems that most of the discussions on the relationships between stability and diversity lead nowhere, particularly because it is difficult, perhaps impossible, to find direct causal relationships between them and to explain stability in terms of diversity or vice versa". (Margalef, 1974b).

If we analyse the use of the term stability in the content indexes of the above mentioned six major books by Margalef (Margalef, 1968; 1974b; 1981; 1983; 1991 and 1997), we noted that this term was important in his first books; later, Margalef lost his interest in this term, and the word disappears completely in the last book (See table 1 for a comparison between the first and the last book). In the 1970s, Margalef tried to develop the concept of stability in a mathematical form (Margalef, 1981; pages 155-158), although he warned about "the heterogeneous use of the term stability by various ecologists". In his book

Table 2. Comparison of the use of the words stability and resilience in the journal Ecology between 1997 and 2014. Vol: Volume, Page: Page number; p/a: Pages per year; Authors: Average number of authors per article (minimum and maximum); Text: Average number of times the word appears in the text (min-max); Biblio: Average number of times the word appears in the references (minimum-maximum). Main topic of the article: ET: Terrestrial Ecology; M: Marine Ecology; L: Limnology; Mod: Models and theoretical articles. Comparación del uso de las palabras estabilidad y resiliencia en la revista "Ecology" entre 1997 y 2014. Vol = Volumen, Pag = Número de páginas; p/a: Páginas por año; Autores: Número medio de autores por artículo (mínimo y máximo); Texto: Número medio de veces que la palabra aparece en el texto (mínimo y máximo); Biblio: Número medio de veces que la palabra aparece en la Bibliografía (mínimo-máximo). Temática principal del artículo: ET = Ecología Terresre; M: Ecología Marina; L: Limnología; Mod: Modelos y artículos teóricos.

\begin{tabular}{cccccccc}
\hline $\mathrm{N}=216$ & Vol & Pag & p/a & Autores & Texto & Biblio & ET/M/L/Mod \\
\hline Stability & 39 & 346 & 9.5 & $3.9(1-23)$ & $14(1-101)$ & $5(0-22)$ & $13 / 4 / 5 / 17$ \\
Resilience & 32 & 342 & 10.5 & $3.8(1-14)$ & $15(0-119)$ & $3.3(0-13)$ & $13 / 8 / 6 / 9$ \\
\hline
\end{tabular}


of 1991, Margalef addressed the issue succinctly on pages 139 to 142 , without proposing any formula to measure it. In this book he defines stability “in its regular use, as... the system's ability to return to a state from which it has been temporarily removed due to a disturbance"; however, he feels uncomfortable using this term because he states that "According to their individual preferences, sometimes related to politics, ecologists describe as stable one situation or its opposite". As I previously said, in his 1997 book, he hardly mentioned the term and did not discuss it with respect to diversity. Stability is one of the few classical terms in Ecology that disappears from Margalef's vocabulary (Table 1).

The idea of Margalef that "...ecologists should abandon the use of the term stability..." is not shared by many today. This term is now present in several papers and textbooks, and ecologists still spend time and effort investigating the stability-diversity relationship. This trend can easily be observed if we analyse the papers published in the journal Ecology since 1997 (Table 2). Since then, 216 issues of the journal have been published. The word stability appears in the summary, title or keywords of 39 papers, totalling 346 pages, or approximately 9.5 pages per paper with an average of 3.92 authors per article (1-23). Apart from the title, abstract and keywords, the word stability is present a total of 534 times in the text and 194 times in the references of the 39 papers, and some of these references are of papers published in Science (6) or Nature (19). It is interesting to note that the word "stability" is present in the summary of certain articles, but it does not appear in the text (in 3 papers). The word stability is more common in papers dealing with conceptual or theoretical issues (17) than in papers dealing with terrestrial (13), marine (4) or freshwater ecology (5). According to its use in the journal Ecology, stability remains a frequently used concept by ecologists and plays an important role in scientific journals. If we compare the use of the term stability in the journals Ecology and Frontiers in Ecology and Environment (two journals published by the Ecological Society of America, ESA), the results are strikingly dif-
Table 3. Number of articles in which the words stability, resilience and sustainability are used in the summary of the two journals published by ESA (Ecological Society of America), i.e., Ecology and Frontiers in Ecology and Environment. Número de artículos en los que en el resumen se utiliza estabilidad, resiliencia o sostenibilidad en dos revistas editadas por la ESA (Ecological Society of America). "Ecology" y "Frontiers in Ecology and Environment".

\begin{tabular}{lcc}
\hline & $\begin{array}{c}\text { Ecology } \\
(\mathrm{N}=216)\end{array}$ & $\begin{array}{c}\text { Frontiers } \\
(\mathrm{N}=132)\end{array}$ \\
\hline Sustainable/Sustainability & 3 & 20 \\
Resilience & 32 & 10 \\
Stability & 39 & 2 \\
\hline
\end{tabular}

ferent. The latter journal has been published only since 2000 and, in a total of 132 issues, the word stability is present only 2 times in the abstracts (Table 3). It seems that stability is not a popular term in the environmental sciences. The overall results for the word stability differ with the results obtained for the words resilience and sustainability (see the following paragraphs).

\section{RESILIENCE}

Resilience is a term that is also commonly used in ecology. One of the most classic and most cited publications in the literature referring to this term is the one by Holling (1973), which relates resilience with stability. It is interesting to note that Margalef did not include the term resilience in the 1968 and 1974b books, even though he cites the work of Holling in the latter book. Of his six major books, only "Limnología" (1983) includes this term. His opinion of the term was the following: "When the pretentious term of stability vanishes, other terms remain (such as resilience) that might have a descriptive value but are certainly not necessary ...". Later, in the same book, when discussing the role of phosphorus in lakes, he states, "Resilience is the ability of a system to return to its initial state". In the same book he also included another definition of resilience as "the ability to leave germs that might influence the future and elastically change the current composition of the system; that is, the stability in the sense of Lyapunov". In 1981, Margalef dis- 
cussed with some detail the Lyapunov concept of stability and, indeed, considered stability and resilience as synonymous terms.

In the same series of papers in the journal Ecology that were previously examined for the term stability, I also looked for the presence of the word resilience in the titles, abstracts and keywords (Table 2). The word resilience appears in 32 issues (out of 216), totalling 342 pages, with an average of 3.8 authors per article. Resilience appears 539 times in the text of the papers examined and 115 times in the references cited. Resilience seems to be a less "respectable" scientific topic than stability because in the 32 papers of the journal Ecology where the term appears, there is no citation of any paper from Science or Nature. Contributions dealing with resilience are less focussed on models (9) and more focussed in terrestrial ecology (13); then, marine (8) and freshwater ecology (6) follow in the ranking (Table 2). In contrast, resilience seems to be a more popular topic in environmental sciences; if we compare its use in both ESA journals, resilience is relatively more commonly used in Frontiers in Ecology and Environment than in Ecology (Table 3). Likewise, I asked if there are papers where the relationship stability-resilience is addressed in these two examined journals. No abstracts or keywords have the two words appeared together; however, in the main text of certain papers, this relationship is examined. From the 32 papers in Ecology that contain the word resilience in the summary, 20 contain the word stability in the text. In contrast, out of the 39 papers where the word stability appears in the summary, only 4 contain the word resilience in the text. It seems that the term stability in ecology is more prevalent than the term resilience, at least in classical journals such as Ecology.

Currently, it seems that the word resilience has gained prominence, as it is used in several disciplines other than Ecology. The term is popular in conference titles and books on several other topics. There is, for example, a Spanish Society of Resilience. Likewise, resilience is a more frequent concept in several scientific fields than stability, which seems to be limited to ecological scientific journals.

\section{SUSTAINABILITY}

The word sustainability is even more popular today than resilience or stability. According to Margalef (1996), “...it is an oxymoron, i.e., a combination of contradictory or incongruous terms as are often present in the proposals that are sheltered under this term". And he warned us, stating that "any comment on this issue depends on what is understood as sustainable" (Margalef, 1996). In his contribution to the book "Diez años después de Estocolmo" (Margalef, 1983b), he stated that "it is clear that science barely had influence on the convening of the Stockholm conference" and that this event "has little impact on the areas of education and research,... although it has encouraged several cosmetic laws and considerable political opportunism". In various courses to which Margalef was invited and where the word sustainability was part of the title of the event, Margalef seemed compelled to talk about this term. He usually was concise. In an article where he discusses the differences between diversity and biodiversity, at the end of a section entitled "On diversity and sustainability" he proposed what should be the key issue of sustainable development: "a decrease in the amount of energy exchanged coupled to a wiser use of the existing information" (Margalef, 1994). In another paper entitled "Dynamics of ecosystems. Where is the world going?" (Margalef, 1997b), he included a section (only half a page) entitled "About Sustainable Development". He proposed an attitude to promote sustainable development "...to practice the virtue of temperance, consume less energy, make a better use of the accumulated past information and wisely select what we accumulate in the present". It seems clear that the word sustainability was not Margalef's favourite, which does not mean that he was not interested in nature and conservation issues of the biosphere as it became clear in several of his writings.

Of the three analysed words, i.e., stability, resilience and sustainability, the latter is rarely used in formal scientific journals, such as Ecology. For this reason I have not included it in Table 2. From 1997 to 2014 , there are only three papers that 
include the word "sustainability" or "sustainable development" among the keywords of the journal Ecology. The situation is the opposite when the keywords of the journal Frontiers in Ecology and Evolution are considered (Table 3).

\section{STABILITY, RESILIENCE AND SUSTAINABILITY IN MARGALEF'S UNIVERSE: A SUMMARY}

Here, I examined the use of the three concepts in two of the most currently used textbooks of General Ecology for undergraduate students (Townsend et al., 2008; Molles 2013). Sustainability is not present in Molles's textbook, whilst in the textbook by Townsend et al., (2008), there is an entire chapter on this concept. It seems that ecologists do not have a unanimous position regarding the need to teach the concept of sustainability as a primary objective in ecology. However, both authors agree in defining stability as a combination of two different ecosystem characteristics, resistance and resilience. Moreover, whilst the former includes the study of both concepts in the chapter on "Succession and stability", the latter only discussed these concepts in a chapter entitled "From populations to communities". In both cases, neither of the two terms plays an important role in the structure of the chapter where they are included. Margalef's opinion about the use of the three words does not seem relevant for these (and several other) textbooks: neither of the two books includes a single reference to any Margalef's paper or book in the list of cited references.

In summary, although ecologists have not renounced to the use of the word stability, this concept does not seem to play a central role in ecology today. Likewise, even though stability has been present in ecology books and is still found in the most established journals such as Ecology, the use of the term must be maintained regardless of whether the term is useful or whether it can or cannot be easily and accurately quantified. Whilst resilience has certain success in traditional ecology, this term is frequently used in environmental sciences and only marginally used in ecology textbooks. The use of the term sustainability seems limited to the environmental sciences, and it is not highly considered in ecological journals such as Ecology. Therefore, the use of those words today does not follow the path that Margalef proposed in his later writings, in which he did not use those concepts as the most relevant to understand the functioning of the biosphere (Margalef, 1997a).

\section{MARGALEF, A FORGOTTEN ECOLOGIST?}

Margalef's ecological ideas distinguished him from others ecologists by the end of the XX century. He was aware of such situation; in the second page of "Our Biosphere", he wrote, "My compilation does not touch everything that I feel is essential in ecology, much less than what most ecologists consider their major interests, judging from the contents of major journals". Despite the several awards he received in life (Huntsman price, Naumann-Thienemann medal and others; see the list in Peters, 2010) and despite that there is an international award that bears his name in Catalonia and in the ASLO (Educational Award), Margalef is practically forgotten by most of his colleagues, especially those working in theoretical ecology or limnology. Only marine ecologists seem to remember his name and work especially through one of his papers that remains frequently cited (Margalef, 1978). According to Bascompte (2012), the cornerstones of his thoughts are 1) The role of information, 2) P/B decrease along succession; 3) The baroque of nature; 4) Man as part of the biosphere; and 5) Asymmetry. However, few of his fellow ecologists seem to have read his books and understood his ideas because they are not mentioned in recent papers or books on ecology. Margalef does not have the place he deserves in the history of ecology.

It is not clear why, in 1997, Margalef still believed in a unifying theory of ecology, as he advocated in his first book. In Chapter X of "Our Biosphere" (Margalef, 1997a), he seems to recognize the impossibility of a unifying ecological theory. 
He hypothesized that nature has only a few rules that he called "principles of impotence", for example, "two things cannot be present simultaneously in the same place, ...the same energy cannot be used twice in continuity and in the same way..."; in addition, he mentioned that "this fundamental aspect of the organization of the world is not exclusive of a physical nature because the organization of a society and the formulation of its ethics are grounded preferably in a few wellchosen ingredients that have a negative mandatory expression (You should not)". Thus, the organization of ecosystems would be bound by limits that cannot be moved because of physical impossibility, but within these limits the possibilities are immense, which would explain the variety and uniqueness of ecosystems and their peculiarities; several possible combinations of interactions give rise to almost endless situations: "the baroque of nature" in Margalef's words.

The ideas advocated by Margalef and his role in modern ecology have hardly been recognized. Therefore, we must insist on highlighting his figure and his most relevant ideas. The events that took place on the $10^{\text {th }}$ anniversary of his death were meant to bridge this gap. Likewise, this paper has the same intentions through the discussion of the three words present in the theme of the XVI Iberian Limnology Congress.

\section{ACKNOWLEDGEMENTS}

The author would like to thank Dr. Tecla Riera for her assistance in searching the literature and David Casanueva from the Library of the Biology Department of the University of Barcelona for helping with the search of Margalef papers in the Web of Science.

\section{REFERENCES}

ARMENGOL, J. 2006. Ramon Margalef (19192004): teacher and researcher. Limnetica, 25: IVII.

ARMENGOL, J., R. MORENO-AMICH \& A. PALAU. 2006.(editors) The ecology of Iberian inland waters: Homage to Ramon Margalef. Limnetica, Vol. 25, 612 páginas.

BASCOMPTE, J. 2012. Pròleg. In: La nostra biosfera. R. Margalef: 9-12. Publicacions de la Universitat de València i Institut d'Estudis Catalans. València. Barcelona.

BONNIN, P. 1994. Ramon Margalef. Fundació Catalana per a la Recerca. Barcelona.

ESTRADA, M. 2008. Explorations on Phytoplankton Diversity. An appreciation of Ramon Margalef's contribution. In: Unity in Diversity. Reflections on Ecology after the legacy of Ramon Margalef. F. Valladares, A. Camacho, A. Elosegui, C. Gracia, M. Estrada, J. C. Senar \& J.M. Gili., (eds). 191222. Fundación BBVA. Bilbao.

FLOS, J. 2005. El concepto de información en la ecología margalefiana. Ecosistemas. 2005/1. http: //www.revistaecosistemas.net/index.php/ecosiste mas/article/view/170.

HOLLING, C. S. 1973. Resilience and stability in ecological systems. Annual Review in Ecology and Systematics, 4: 1-23.

GRACIA, C. 2008. A human and scientific portrait of Ramon Margalef (1919-2004). In: Unity in Diversity. Reflections on Ecology after the legacy of Ramon Margalef. F. Valladares, A. Camacho, A. Elosegui, C. Gracia, M. Estrada, J. C. Senar \& J. M. Gili., (eds). 21-38. Fundación BBVA. Bilbao.

MARGALEF, R., 1968 Perspectives in Ecological Theory. University of Chicago Press, (Edición Española, 1978, Editorial Blume).

MARGALEF, R. 1969. Diversity and stability. Brookhaven Symposium Biology, 22: 25-37.

MARGALEF, R. 1974a. Ecología. Omega. Barcelona.

MARGALEF, R. 1974b. Diversity, stability and maturity in natural ecosystems. In: Unifying concepts in ecology. In: W. H. Van Dobben \& R. H. LoweConnell (eds): 151-160. Junk, The Hague. The Netherlands.

MARGALEF, R. 1975. External factors and ecosystem stability. Schweizerische Zeitschrift für $\mathrm{Hy}$ drologie, 37: 108-117.

MARGALEF, R. 1977. Stability and change in complex systems. In: Étude et gestion du système marin. I. Elskens, A. Sanfeld. \& J. Vigneron, (eds.). IVème session. 99-126, Louvain-la-Neuve, Université Libre de Bruxelles.

MARGALEF, R. 1978. Life-forms of phytoplankton as survival alternatives in an unstable environment. Oceanologica acta, 1: 493-509. 
MARGALEF, R. 1981. La Biosfera entre la termodinámica y el juego. Omega. Barcelona.

MARGALEF, R. 1983a. Limnología. Omega. Barcelona.

MARGALEF, R. 1983b. La ciencia ecológica y los problemas ambientales técnicos, sociales y humanos. In: Diez años después de Estocolmo. Desarrollo, Medio ambiente y supervivencia: 177-200 CIFCA. Madrid.

MARGALEF, R. 1991. Teoría de los sistemas ecológicos. Universitat de Barcelona.

MARGALEF, R. 1994. Diversity and biodivesity Their possible meaning in relation with the wish for sustainable management. Anais Academia Brasileira Ciencias, 66 (Supl.1): 3-14.

MARGALEF, . 1996. Una ecología renovada a la medida de nuestros problemas. Fundación César Manrique.

MARGALEF, R. 1997a. Our biosphere. Excellence in Ecology. Ecology Institute 176 pp. (La Nostra biosfera, Catalan translation of Jaume Terrades in 2012, Published by Universitat de València e Institut d'Estudis Catalans).

MARGALEF, R. 1997b. Dinámica de los Ecosistemas: ¿Hacia dónde camina el planeta?. In: La interpretación de la problemática ambiental: Enfoques Básicos(I). M. Novo \& R. Lara (Coords.): 75 97. Ed. Fundación Universidad Empresa. Madrid.
MOLLES, M. C. Jr. 2013. Ecology. Concepts and Apllications. Sixth edition. McGraw Hill.

ORIANS, G. H. 1974. Diversity, stability and maturity in natural ecosystems. In: Unifying concepts in ecology. In: W. H. Van Dobben \& R. H. LoweConnell (eds): 139-150. Junk, The Hague. The Netherlands.

PETERS, F. 2010. Ramon Margalef, the curiosity driven life of a self-taught naturalist. ASLO, Waco. USA.

PRAT, N. 2015. Ramón Margalef (1919-2004). Una obra ingente no totalmente bien reconocida. Ecosistemas, 24(1): 97-103

ROS, J. D. 2006. Professor RAMON MARGALEF (1919-2004). Biography and Bibliography. Contributions to Science, 3(2): 297-317.

TOWNSEND, C., BEGON, M. \& HARPER, J. L. 2008. Essentials of Ecology. Thrid Edition. Blackwell.

VALLADARES, F., A. CAMACHO, A. ELOSEGUI, C. GRACIA, M. ESTRADA, J. C. SENAR \& J. M. GILI, (eds). 2008. Unity in Diversity. Reflections on Ecology after the legacy of Ramon Margalef. Fundación BBVA. Bilbao.

ZAMORA, R., S. SABATER \& J. CORTINA. 2005 (eds). Homenaje a Ramón Margalef. Ecosistemas, Vol 14, 1. http://www.revistaecosistemas.net/index. $\mathrm{php} / \mathrm{ecosistemas/issue/view/21}$ 